\title{
New Biflavonoid and Other Constituents from Luxemburgia nobilis (EICHL)
}

\author{
Márcia C. C. de Oliveira ${ }^{a}$, Mário G. de Carvalho ${ }^{a *}$, Cleber J. da Silva ${ }^{a}$ and Alceni A. Werle \\ ${ }^{a}$ Departamento de Química - ICE, Universidade Federal Rural do Rio de Janeiro, 23851-970, Seropédica - RJ, Brazil \\ ${ }^{b}$ Departamento de Química - ICEB, Universidade Federal de Ouro Preto, 35400-000, Ouro Preto - MG, Brazil
}

\begin{abstract}
O fracionamento cromatográfico dos extratos orgânicos das folhas e galhos de Luxemburgia nobilis (Ochnaceae) forneceu o sitosterol, sitosterol-3-O- $\beta$ D-glicopiranosil, friedelina, friedelinol, a mistura dos triterpenos lupeol, $\alpha$-amirina e $\beta$-amirina, rutina, epicatequina, uma mistura de duas chalconas, isoliquiritigenina e 3'-hidróxiisoliquiritigenina, duas biflavonas conhecidas, amentoflavona e robustaflavona além de uma biflavona nova, 5,7,4'-triidróxiflavona-(3'-O-4"')-5",7”diidróxiflavanona. As estruturas foram definidas através dos dados espectrométricos incluindo experimentos bidimensionais de RMN das substâncias naturais e dos derivados metilados e acetilados da biflavona nova.
\end{abstract}

Chromatographic fractionation of the organic extracts from the leaves and branches of Luxemburgia nobilis (Ochnaceae) afforded sitosterol, sitosterol-3-O- $\beta$ D-glucopyranoside, friedelin, friedelinol, a mixture of triterpenes lupeol, $\alpha$-amyrin and $\beta$-amyrin, rutin, epicatechin, a mixture of two chalcones, 2,4,3',4'-tetrahydroxychalcone and 2,4,4'-trihydroxychalcone, two known biflavones, amentoflavone and robustaflavone along with a new biflavonoid, 5,7,4'-trihydroxyflavone-(3'-O4"')-5",7"-dihydroxyflavanone. The structures were established from spectral data, including 2DNMR experiments of the natural substances and of the acetyl and methyl ether derivatives of the new biflavone.

Keywords: Luxemburgia nobilis, Ochnaceae, flavonoids, steroids, triterpenes

\section{Introduction}

The Ochnaceae family has been characterized as a major source of biflavonoids and up to now it has been best represented by Ouratea, ${ }^{1-5}$ Ochna $^{6-9}$ and Lophira ${ }^{10-12}$ genera. In a previous report, we described the inhibition of murine tumor growth, antiproliferative effects and activation of apoptosis on Erlich tumor cells by flavones isolated from Ouratea hexasperma ${ }^{13}$ and from Ouratea semisserrata. ${ }^{14}$ There is only one record of a phytochemical work on a Luxemburgia genus where we described the isolation and identification of steroids, fatty acids, betulinic acid, the diterpene epimanoyl oxid, atranorin and two new triglycerides. ${ }^{15}$

In this paper, we report the structure determination of a new biflavonoid, 2",3"-dihydroochnaflavone, two known biflavones, amentoflavone and robustaflavone, the flavonoids rutin, epicatechin, and two chalcones, along with fatty acids, sitosterol, 3-O- $\beta$-D-glucopyranosyl-

*e-mail: mgeraldo@ufrrj.br sitosterol and five pentacyclic triterpenes isolated from the branches and leaves of L. nobilis.

\section{Results and Discussion}

The chromatographic fractionation of the methanol extract from the branches and also of the hexane, ethyl acetate and methanol extracts from the leaves of $L$. nobilis afforded hexadecanoic, eicosanoic and tetraeicosanoic acids, a new biflavonoid, 2",3"-dihydroochnaflavone (1); two known biflavones, amentoflavone (2) and robustaflavone (3); epicatechin (4); two chalcones, isoliquiritigenin (5) and 3'-hydroxyisoliquiritigenin (6); rutin (7); sitosterol (8); sitosterol 3-O- $\beta$-D-glucopyranoside (9); friedelin (10); friedelinol (11) and a mixture of lupeol (12), $\alpha$-amyrin (13) and $\beta$-amyrin (14).

The ${ }^{13} \mathrm{C}$ NMR spectrum of compound $\mathbf{1}$ shows 28 signals including two signals at $\delta_{\mathrm{CH}} 128.80$ and 116.30 , each representing two carbon atoms, eight $\mathrm{sp}^{2} \mathrm{CH}$, two $\mathrm{sp}^{3}$ carbons $\left(\delta_{\mathrm{CH}} 78.57\right.$ and $\left.\delta_{\mathrm{CH} 2} 42.38\right)$, fourteen $\mathrm{sp}^{2}$ quaternary carbons $(4 \mathrm{xC}$ and $10 \mathrm{xC}-\mathrm{O})$ and two carbonyl groups $\left(\delta_{\mathrm{C}}\right.$ 182.22 and 196.48). The ${ }^{1} \mathrm{H}$ NMR spectrum shows two 
signals at $\delta 11.99$ and 12.71 indicating the presence of two chelated hydroxyls, which were confirmed by the IR spectrum which exhibits a broad $\mathrm{OH}$ absorption band at $3495 \mathrm{~cm}^{-1}$ and also a chelated carbonyl absorption at $1646 \mathrm{~cm}^{-1}$. The NMR spectrum shows ten aromatic hydrogen signals including two sets of meta-coupled doublets $\left({ }^{1} \mathrm{H},{ }^{1} \mathrm{H}-\mathrm{COSY}\right)$ at $\delta 6.11$ and $6.37(2.0 \mathrm{~Hz})$ and $\delta 5.81$ and $5.82(2.1 \mathrm{~Hz})$ which belong to the $\mathrm{H}-6$ and $\mathrm{H}-8$ atoms of two flavonoid moieties. These data are in agreement with a flavonoid dimeric structure. The molecular formula $\mathrm{C}_{30} \mathrm{H}_{20} \mathrm{O}_{10}$, which was obtained by HREIMS $m / z\left[\mathrm{M}^{+}, 30\right] 540.10565$ (calc. 540.10050 for $\mathrm{C}_{30} \mathrm{H}_{20} \mathrm{O}_{10}$ ) confirms the latter observation. The presence of a singlet at $\delta 6.62$ (one hydrogen) and three double doublets at $\delta 5.39(16.6$, and $12.7 \mathrm{~Hz}), 3.11(16.6,12.7 \mathrm{~Hz})$ and $2.66(16.6,6.0 \mathrm{~Hz})$ led us to propose a flavone and flavanone unit for the dimer. The data above imply that carbons 6 and 8 of each unit are not involved in the interflavonoid linkage. Ring B of the flavone unit was identified by three hydrogen signals at $\delta 7.06(\mathrm{~d}, 8.7 \mathrm{~Hz})$, $7.62(\mathrm{~d}, 2.0 \mathrm{~Hz})$ and $7.80(\mathrm{dd}, 8.7$ and $2,0 \mathrm{~Hz})$ corresponding to H-5', H-2' and H-6' of this moiety. Furthermore, the ${ }^{1} \mathrm{H}$ NMR spectrum also shows a set of AA'BB' doublets ( $J 7.8$ $\mathrm{Hz}, 2 \mathrm{H}$ each) at $\delta 7.36$ and 6.83 which were assigned to $\mathrm{H}$ 2 ", 6" and H-3" ,5" of the flavanone moiety, respectively. The cross peaks observed in the ${ }^{13} \mathrm{C},{ }^{1} \mathrm{H}-\mathrm{COSY}^{-}{ }^{\mathrm{n}} \mathrm{J}_{\mathrm{CH}}(\mathrm{n}=2$ and 3, HMBC) spectra of 1 show heteronuclear long-range couplings of C-1'with $\mathrm{H}-5$ ' and of C-1"' with H-3"',5", which confirm rings $\mathrm{B}$ of both flavone and flavanone, respectively. These observations and comparison of the UV absorption maxima (288 and $332 \mathrm{~nm}$ ) and NMR data with those of the biflavonoid 2,3-dihydroochnaflavone, isolated from Ochna obtusata, ${ }^{6}$ revealed these to be identical compounds. The differences between the chemical shift of the AA'BB' hydrogen in $\mathbf{1}[\delta 7.36$ and $6.83(\mathrm{~d}, 7.8 \mathrm{~Hz}, 2 \mathrm{H}$ each)] and the values for the same set for the 2,3-dihydroochnaflavone reported in the literature ${ }^{6}$ [ $\delta 8.03$ and $7.08(\mathrm{~d}, 9.0 \mathrm{~Hz}, 2 \mathrm{H})]$ led to propose the 2", 3"'-

Table 1. ${ }^{1} \mathrm{H}(500 \mathrm{MHz})$ and ${ }^{13} \mathrm{C}(125 \mathrm{MHz}) \mathrm{NMR}$ spectra data for biflavonoid $1\left(\mathrm{D}_{3} \mathrm{COD}\right)$ and its trimethyl ether derivative $\left.1 \mathrm{a}\left(\mathrm{D}_{3} \mathrm{CCOCD}\right)_{3}\right)$ Chemical shifts are in $\delta(\mathrm{ppm})$ and coupling constants $(J$, in parenthesis) in $\mathrm{Hz}$.

\begin{tabular}{|c|c|c|c|c|}
\hline \multirow[b]{2}{*}{$\mathbf{C}$} & \multicolumn{2}{|l|}{1} & \multicolumn{2}{|l|}{$\mathbf{1 a}$} \\
\hline & $\delta_{\mathrm{C}}$ & $\delta_{\mathrm{H}}$ & $\delta_{\mathrm{C}}$ & $\delta_{\mathrm{H}}$ \\
\hline 2 & 163.94 & - & 162.54 & - \\
\hline 4 & 182.22 & - & 182.64 & - \\
\hline 5 & 161.80 & - & 158.97 & - \\
\hline 7 & 164.66 & - & 164.71 & - \\
\hline 9 & 157.82 & - & 158.00 & - \\
\hline 10 & 104.29 & - & 106.00 & - \\
\hline 1 ' & 122.72 & - & 123.00 & - \\
\hline 3 ' & 142.88 & - & 143.00 & - \\
\hline 4 ' & 153.84 & - & 153.69 & - \\
\hline 4" & 196.48 & - & 196.84 & - \\
\hline $5 "$ & 163.45 & & 163.85 & - \\
\hline 7" & 167.14 & - & 168.39 & - \\
\hline $9 "$ & 163.28 & - & 166.19 & - \\
\hline $10 "$ & 102.30 & - & 101.00 & - \\
\hline 1 '” & 132.77 & - & 131.51 & - \\
\hline $4, "$, & 158.45 & - & 155.69 & - \\
\hline $\mathbf{C H}$ & \multicolumn{2}{|c|}{${ }^{13} \mathrm{C}-{ }^{1} \mathrm{H}-\mathrm{COSY}-{ }^{1} J_{\mathrm{CH}}$} & \multicolumn{2}{|c|}{${ }^{13} \mathrm{C}-{ }^{1} \mathrm{H}-\mathrm{COSY}-{ }^{-1} J_{\mathrm{CH}}$} \\
\hline 3 & 103.91 & $6.62(\mathrm{~s})$ & 106.75 & $6.51(\mathrm{~s})$ \\
\hline 6 & 99.51 & $6.11(\mathrm{~d}, J 2.0 \mathrm{~Hz})$ & 98.36 & $6.50(\mathrm{~s})$ \\
\hline 8 & 94.64 & $6.37(\mathrm{~d}, J 2.0 \mathrm{~Hz})$ & 94.15 & $6.17(\mathrm{~s})$ \\
\hline 2 ' & 121.22 & $7.62(\mathrm{~d}, J 7.8 \mathrm{~Hz})$ & 120.75 & $7.64(\mathrm{~s})$ \\
\hline $5^{\prime}$ & 118.41 & $7.06(\mathrm{~d}, J 7.0 \mathrm{~Hz})$ & 113.85 & $7.21(\mathrm{~d}, J 8.0 \mathrm{~Hz})$ \\
\hline 6 ' & 125.35 & $7.71(\mathrm{dd}, J 7.8$ and $2.0 \mathrm{~Hz})$ & 125.12 & $7.80(\mathrm{~d}, J 8.0 \mathrm{~Hz})$ \\
\hline $2 "$ & 78.57 & $5.39(\mathrm{dd}, J 6.0$ and $12.7 \mathrm{~Hz})$ & 75.17 & $5.42(\mathrm{br} \mathrm{d}, J 12.0 \mathrm{~Hz})$ \\
\hline $6 "$ & 96.58 & $5.81(\mathrm{~d}, J 2.0 \mathrm{~Hz})$ & 95.03 & $5.92(\mathrm{~s})$ \\
\hline $8 ”$ & 95.62 & $5.82(\mathrm{~d}, J 2.0 \mathrm{~Hz})$ & 92.83 & $5.89(\mathrm{~s})$ \\
\hline $2, " / 6, "$ & 128.80 & $7.36(\mathrm{~d}, J 7.8 \mathrm{~Hz})$ & 128.56 & $7.38(\mathrm{~d}, J 8.0 \mathrm{~Hz})$ \\
\hline $3^{\prime}, / 5, "$ & 116.30 & $6.83(\mathrm{~d}, J 7.8 \mathrm{~Hz})$ & 116.32 & $6.83(\mathrm{~d}, J 8.0 \mathrm{~Hz})$ \\
\hline \multicolumn{5}{|l|}{$\mathrm{CH}_{2}$} \\
\hline $3 "{ }^{2}$ & 42.38 & $3.11(\mathrm{dd}, J 12.7$ and 16.6$)$ & 43.01 & $3.04(\mathrm{dd}, J 12.0$ and $16.0 \mathrm{~Hz})$ \\
\hline & & $2.66(\mathrm{br} \mathrm{d}, 16.6 \mathrm{~Hz})$ & & $2.70(\mathrm{dd}, J 6.0$ and $16.0 \mathrm{~Hz})$ \\
\hline \multicolumn{5}{|r|}{ 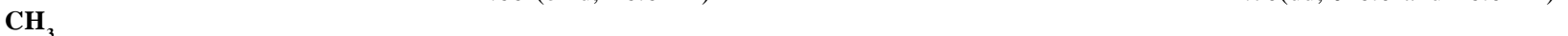 } \\
\hline MeÖ-7 & - & & 55.38 & $3.78(\mathrm{~s})$ \\
\hline $\mathrm{MeO}-4$ & - & & 56.11 & $3.70(\mathrm{~s})$ \\
\hline MeO-7" & - & & 55.76 & $3.77(\mathrm{~s})$ \\
\hline $\mathrm{HO}-5$ & - & $12.71(\mathrm{~s})$ & - & $12.66(\mathrm{~s})$ \\
\hline HO-5" & - & $11.99(\mathrm{~s})$ & - & $11.88(\mathrm{~s})$ \\
\hline
\end{tabular}


dihydroochnaflavone structure for $\mathbf{1}$. The treatment of $\mathbf{1}$ with diazomethane yielded 1a with three methoxy groups and two chelated hydroxyls. The results obtained from NOEDIFF-NMR experiments on this derivative, performed with irradiation at the methoxy groups did not reveal any signal enhancements at the doublet at $\delta 7.62(\mathrm{~d}, 2.0 \mathrm{~Hz}$, $\mathrm{H}-2$ ') and at 7.36 (d, $7.80 \mathrm{~Hz}, \mathrm{H}-3$ "',5"') but did show nOe at the doublets at $\delta 7.06(\mathrm{H}-5$ '), $6.11(\mathrm{H}-6), 6.37(\mathrm{H}-8)$ $5.81(\mathrm{H}-6$ ") and 5.82 (H-8"). These observations further confirm the C-3'-O-C-4'" connection between the flavone and flavanone moieties. The comparison of the ${ }^{13} \mathrm{C}$ NMR spectral data of $\mathbf{1}$ with those of 2,3-dihydroochnaflavone ${ }^{6}$ along with the analysis of the ${ }^{13} \mathrm{C},{ }^{1} \mathrm{H}-\mathrm{COSY},{ }^{\mathrm{n}} J_{\mathrm{CH}}(\mathrm{n}=1$, HMQC, Table $1 ; \mathrm{n}=2$ and $3, \mathrm{HMBC}$ ) allowed to define the structure of 1 as the new biflavonoid 4',5,7-trihydroxyflavone-(3'-O-4"')-5",7"-dihydroxyflavanone or 2",3"dihydroochnaflavone. The ${ }^{1} \mathrm{H}$ and ${ }^{13} \mathrm{C}-\mathrm{NMR}$ data of $\mathbf{1 b}$ were used to confirm the proposed structure.

Compounds 2, $\mathbf{3}$ and $\mathbf{4}$ were characterized as amentoflavone, epicatechin and robustaflavone, respectively, with the help of 1D and 2D ${ }^{1} \mathrm{H}$ and ${ }^{13} \mathrm{C}$ NMR analysis of the natural substances and comparison with literature data. ${ }^{16-20}$

The molecular formulas of $\mathbf{5}$ and $\mathbf{6}$ were determined to be $\mathrm{C}_{15} \mathrm{H}_{12} \mathrm{O}_{4}$ and $\mathrm{C}_{15} \mathrm{H}_{12} \mathrm{O}_{5}$ from the low-resolution mass spectrum, which showed peaks at $m / z 256(5)$ and $272(6)$, in combination with the ${ }^{1} \mathrm{H}$ and ${ }^{13} \mathrm{C}$-NMR spectra (HBBD and DEPT). The 1D and 2D ${ }^{1} \mathrm{H}\left({ }^{1} \mathrm{H},{ }^{1} \mathrm{H}-\mathrm{COSY}\right.$ and NOESY) and ${ }^{13} \mathrm{C}$-NMR (HMQC and HMBC) spectra of the mixture of 5 and $\mathbf{6}$ were analyzed and compared with those of isoliquiritigenin (5) reported in the literature ${ }^{21}$. The remaining hydrogen and carbon-13 signals observed in the 1D and 2D NMR spectra along with the peak with $\mathrm{m} / \mathrm{z}$ 172 in the mass spectrum were used to assign the additional structure in the mixture as the chalcone $2,4,3^{\prime}, 4^{\prime}$ tetrahydroxychalcone $(\mathbf{6})$ registered in the literature. ${ }^{22}$

Compound 7 was characterized as rutin by $1 \mathrm{D}$ and 2D ${ }^{1} \mathrm{H}$ and ${ }^{13} \mathrm{C}$ NMR spectral analysis of the natural substances and comparison with literature data. ${ }^{20}$ The treatment of $\mathbf{7}$ with diazomethane followed by treatment with $\mathrm{Ac}_{2} \mathrm{O}$ and pyridine yielded 7a, with three methoxyl and seven acethyl groups. The results obtained from NOEDIFF-NMR experiments on this derivative performed with irradiation at the methoxyl groups did not reveal signal enhancements of hydrogens bound to anomeric carbons but showed nOe at the doublets at $\delta 6.19(\mathrm{H}-6), 6.39(\mathrm{H}-8), 7.52-7.55\left(\mathrm{H}-2^{\prime}\right)$ and $6.84(\mathrm{H}-5$ '). These observations further confirm the C-

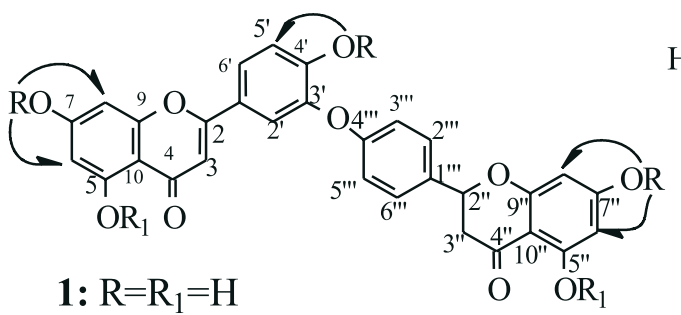

1a: $\mathrm{R}=\mathrm{CH}_{3}, \mathrm{R}_{1}=\mathrm{H} ; \frown$ n.O.e.

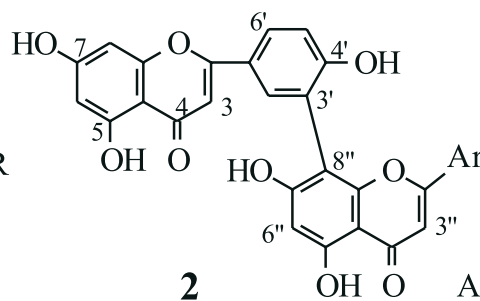

2<smiles>[R]c1ccc(C=CC(=O)c2ccc(O)cc2O)cc1[R]</smiles>

5: $\mathrm{R}_{1}=\mathrm{OH}, \mathrm{R}_{2}=\mathrm{H}$

6: $\mathrm{R}_{1}=\mathrm{R}_{2}=\mathrm{OH}$<smiles></smiles>

1b: $\mathrm{R}=\mathrm{R}_{1}=\mathrm{Ac}$<smiles>C[14C@@H]1Cc2c(O)cc(O)cc2O[C@H]1c1ccc(O)c(O)c1</smiles>

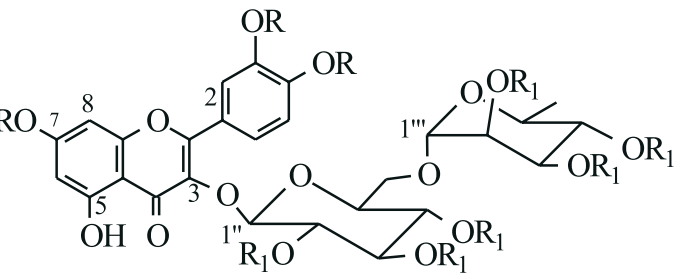

7: $\mathrm{R}=\mathrm{R}_{1}=\mathrm{H}$ $\mathrm{RO}$

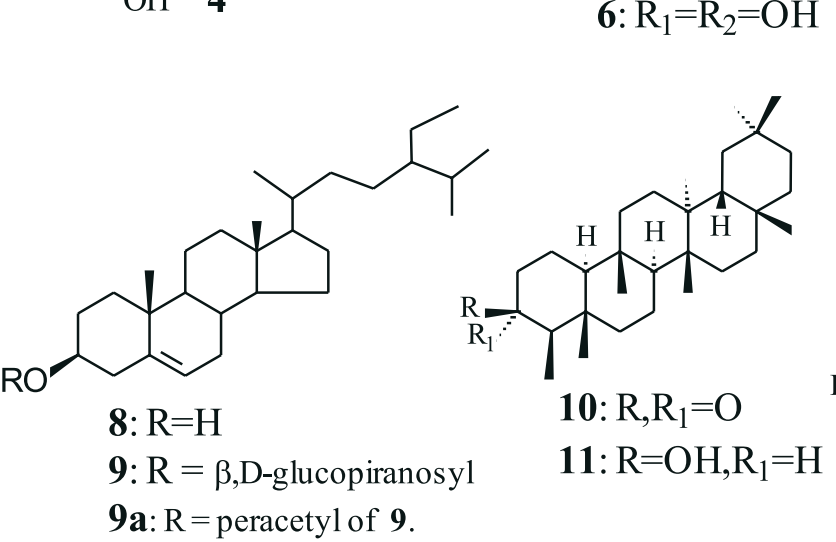

10: $\mathrm{R}, \mathrm{R}_{1}=\mathrm{O}$

11: $\mathrm{R}=\mathrm{OH}, \mathrm{R}_{1}=\mathrm{H}$

9: $R=\beta, D$-glucopiranosyl

9a: $R=$ peracetyl of 9 .

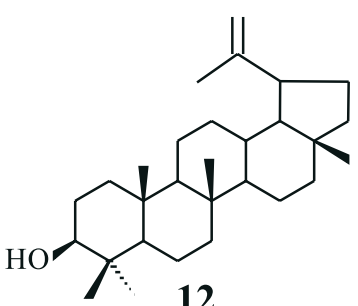

12 a: $\mathrm{R}=\mathrm{CH}_{3}, \mathrm{R}_{1}=\mathrm{Ac}$ 
3-O-glycosyl moiety in the flavone and allowed to identify

7 as rutin. ${ }^{22,23}$

The known natural steroid $\mathbf{8}$, its glycoside $\mathbf{9}$ and the terpenoids 10-14 were identified by analysis of their spectral data including the acetyl derivative 9a and comparison with literature values, mainly ${ }^{13} \mathrm{C}$ NMR chemical shifts described for sitosterol (8), ${ }^{24,25}$ sitosterol$3 \mathrm{O}-\beta$-D-glycopiranoside $(\mathbf{9})^{26}$ and the mixture of lupeol, $\alpha$-amyrin and $\beta$-amyrin (12-14), friedelin (10) and friedelinol (11).$^{27,28}$

\section{Experimental}

\section{General procedure}

Mp's are uncorrected. NMR spectra in $\mathrm{CD}_{3} \mathrm{OD}(\mathbf{1}, \mathbf{2}, \mathbf{3})$ or $\mathrm{CDCl}_{3}$ (1a) were recorded on Bruker spectrometers (200 and $500 \mathrm{MHz}$ for ${ }^{1} \mathrm{H}$ and 50.3 and $125 \mathrm{MHz}$ for ${ }^{13} \mathrm{C}$, respectively) and on a Varian Unity $400\left(400 \mathrm{MHz}\right.$ for ${ }^{1} \mathrm{H}$ and $100 \mathrm{MHz}$ for ${ }^{13} \mathrm{C}$ ) spectrometer using TMS as internal standard. EIMS: direct inlet at $70 \mathrm{eV}$ on a VG Auto Spec300 spectrometer; CC: silica gel (Merck and Aldrich 0.05$0.20 \mathrm{~mm}$ ); TLC: silica gel H or G (Merck and Aldrich) was used to analyse the fractions collected from $\mathrm{CC}$ with visualization by UV (254 and 366) and exposure to iodine vapor; UV: recorded in $\mathrm{MeOH}$ with a DMS 80 Varian spectrophotometer; IR spectra were recorded on $\mathrm{KBr}$ disks on a Perkin-Elmer 1420 spectrophotometer.

\section{Plant material}

Luxemburgia nobilis (Ochnaceae) was collected in Morro de São Sebastião, Ouro Preto, Minas Gerais, Brazil and authenticated by botanist Jorge L. Silva. A voucher specimen (№ 6737) is deposited at the Herbário José Badini of the Instituto de Ciências Exatas e Biológicas of the Universidade Federal de Ouro Preto, Minas Gerais state, Brazil.

\section{Extraction and isolation}

Dried and powdered leaves and branches were successively extracted by maceration using organic solvents at room temperature. The solvents were removed under vacuum to yield residues from Hexane (LNLH, $2.0 \mathrm{~g}$ ), ethyl $\underline{\text { Acetate }}$ (LNLA, $17.7 \mathrm{~g}$ ) and Methanol (LNLM, $20 \mathrm{~g}$ ) from the Leaves and Hexane (LNBH, $3.85 \mathrm{~g}$ ) and Methanol (LNBM, $20.0 \mathrm{~g}$ ) from the Branches of $L$. nobilis. The LNLH residue was fractionated on a silica gel column (A) using hexane, $\mathrm{CH}_{2} \mathrm{Cl}_{2}$ and methanol increasing the polarity to $100 \%$ methanol. The A-1/4,
A-6/9 and A-31/35 fractions were crystallized and yielded hexadecanoic acid (mp $68^{\circ} \mathrm{C}, 200.0 \mathrm{mg}$, acetone), a mixture of tetraeicosanoic and eicosanoic acids ( $130.0 \mathrm{mg}$, acetone) and sitosterol (8, $97.0 \mathrm{mg}$, hexane). The LNLA residue was chromatographed on a silica gel column (B) using $\mathrm{CH}_{2} \mathrm{Cl}_{2} / \mathrm{MeOH}$ increasing the polarity to $100 \% \mathrm{MeOH}$. The B-1/48 fractions were fractionated on a flash column of silica gel using $\mathrm{CHCl}_{3}$ and yielded friedelin (10, $\mathrm{mp}$ $300{ }^{\circ} \mathrm{C}, 107.0 \mathrm{mg}$ ). Fractions B-49/54 and B-55/64 were filtered on silica gel and sephadex columns using $\mathrm{CHCl}_{3} /$ $\mathrm{MeOH}(9: 1)$ and afforded biflavone 2 (88.80 $\mathrm{mg}$ ) and biflavone 1 (130.0 mg), respectively. The LNLM residue was fractionated on a silica gel column $(\mathbf{C})$ using ethyl acetate increasing the polarity to $100 \%$ methanol. Fractions C-10/15 were filtered on a Sephadex column and purified by preparative TLC using $\mathrm{CHCl}_{3} / \mathrm{MeOH}$ and yielded triterpenes friedelinol $\left(\mathbf{1 1}, \mathrm{mp} 301{ }^{\circ} \mathrm{C}, 45 \mathrm{mg}\right)$ and friedelin (10,53 mg); fractions $\mathbf{C}-26 / 30$ were dissolved in methanol and after addition of $\mathrm{CHCl}_{3}$ afforded a precipitate corresponding to the biflavone $\mathbf{3}$ (gum, $50.0 \mathrm{mg}$ ). Fractions C-32-39 yielded $\mathbf{1}\left(\mathrm{mp} 220^{\circ} \mathrm{C}, 295.0 \mathrm{mg}\right)$ after precipitation from acetone. The work up of residue LNBH has been previously described. ${ }^{15}$ Finally, LNBM residue was subjected to column chromatography (D) on silica gel using ethyl acetate/methanol increasing the polarity to $100 \%$ methanol. Fraction D-2 was purified with a silica gel column and preparative TLC using $\mathrm{CHCl}_{3} / \mathrm{MeOH}(9: 1)$ to yield a mixture of triterpenes lupeol (12), $\beta$-amyrin (13) and $\alpha$-amyrin (14) (80.0 mg) besides epicatechin (4, oil, $30.0 \mathrm{mg}$ ). Fractions D-8/12 were filtered on a silica gel column using $\mathrm{CH}_{2} \mathrm{Cl}_{2} / \mathrm{MeOH}$ (7:3) affording epicatechin (4, $200 \mathrm{mg})$. Fractions D-18/20 yielded a residue identified as $3 \mathrm{O}-\beta \mathrm{D}$-glucopyranosylsitosterol $\left(\mathbf{9}, \mathrm{mp} 300^{\circ} \mathrm{C}, 35.0 \mathrm{mg}\right)$. Filtration on sephadex column of fractions D-33/35 yielded two fractions which were recrystallized from EtOAc:MeOH (9:1) and further purified by preparative TLC affording the same glycoside $9(85.00 \mathrm{mg})$ and a mixture of chalcones 5 and 6. Compound 7 (1.00 g), known as rutin, was obtained from filtration of D-36/63 with sephadex using $\mathrm{MeOH}$ as solvent.

4',5,7-trihydroxyflavone-(3'-O-4"')-5", 7',-dihydroxyflavanone (1): $\mathrm{mp} 220^{\circ} \mathrm{C}$ (EtOAc). UV: $\lambda_{\max }{ }^{\mathrm{MeH}} / \mathrm{nm}(\log \varepsilon)$ : $288(3,29), 332(3,42) \mathrm{nm}$. $[\alpha]_{\mathrm{D}}:+7.0\left(\mathrm{Me}_{2} \mathrm{CO}, \mathrm{c} 0.6\right)$, IR $v_{\max } / \mathrm{cm}^{-1}: 3433,3096,1773,1693,1646,1617,1507$, 1473, 1428, 1371, 1337, 1266, 1193, 1130, 1077, 1030, 902, 841(KBr). ${ }^{1} \mathrm{H}$ NMR (500 MHz, methanol-d $\mathrm{d}_{4}$ ) and ${ }^{13} \mathrm{C}$ NMR (125 MHz, methanol-d $)$, Table-1; EI-MS (70 ev), $m$ / $z(\%)\left[\mathrm{M}^{+}, 540\right.$ (13)], 389 (6), 314 (5), 286 (5), 272 (11), 212 (7), 179 (5), 166 (11), 152 (29), 137 (16), 126 (100), 110 (26), 97 (20), 81 (23), 69 (47), 57 (34); HREIMS m/z $\left[\mathrm{M}^{+}\right] 540.10565$ (calcd 540.10050 for $\mathrm{C}_{30} \mathrm{H}_{20} \mathrm{O}_{10}$ ). 
4',7-dimethoxy-5-hydroxyflavone-(3'-O-4"')-7"'methoxy-5"-hydroxyflavanone (1a), trimethyl ether of $\mathbf{1}$ : Prepared by treating a methanol solution of $\mathbf{1}(20 \mathrm{mg})$ with ethereal diazomethane. After evaporation of the solvent, the residue was dissolved in acetone and purified by $\mathrm{CC}$ on silica gel. A fraction eluted with acetone yielded 1a $(20 \mathrm{mg}): \mathrm{mp} 186^{\circ} \mathrm{C}$ (AcOEt). UV: $\lambda_{\max }{ }^{\mathrm{MeOH}} / \mathrm{nm}(\log \varepsilon): 210$ (3.60), 270 (3.20), 380 (3.2), 330 (3.06). IR $v_{\max } / \mathrm{cm}^{-1}: 3443$, 3076, 2935, 2840, 1643, 1612, 15606, 1440, 1378, 1266, 1115, $1160893(\mathrm{KBr}) ;{ }^{1} \mathrm{H}\left(400 \mathrm{MHz}, \mathrm{D}_{3} \mathrm{CCOCD}_{3}\right) ;{ }^{13} \mathrm{C}$ $\left(50.3 \mathrm{MHz}, \mathrm{CDCl}_{3}\right)$ NMR, Table-1. ${ }^{1} \mathrm{H}-\mathrm{NMR}-\mathrm{NOEDIFF}$ in $\mathrm{CDCl}_{3}$.

Peracetyl derivative of $\mathbf{1}(\mathbf{1 b})$ : The peracetate of $\mathbf{1}(\mathbf{1 b})$, was prepared with $\mathrm{Ac}_{2} \mathrm{O}$, pyridine and DMAP at room temperature for $24 \mathrm{~h}$ and was isolated as colorless needles from acetone: $\mathrm{mp} 230{ }^{\circ} \mathrm{C}$; IR $v_{\max } / \mathrm{cm}^{-1} 1772,1694,1646$ $(\mathrm{KBr}) ;{ }^{1} \mathrm{H} \mathrm{NMR}\left(200 \mathrm{MHz}, \mathrm{CDCl}_{3}\right): \delta$ 7,64 (dd, $1 \mathrm{H}, J 8.5,2.0$ $\mathrm{Hz}, \mathrm{H}-6$ ') 7.45 (d, 1H, J2.0 Hz, H-2'), $7.44(\mathrm{~d}, 2 \mathrm{H}, J 8.8 \mathrm{~Hz}, \mathrm{H}-$ 2'”, 6"'), 7.30 (d, 1H, J 8.5, H-5'), 7.27 (d, 1H, J 2.2 Hz, H-8), 7.05 (d, 2H, J 8.8 Hz, H-3"', 5'”), 6.82 (d, 1H, J 2.2 Hz, H-6), 6.78 (d, 1H, J2.2 Hz, H-8"), 6.52 ( d, 1H, J2.2 Hz, H-6"), 6.51 (s, 1H, H-3), 5.48 (dd, J 13.08, 2.8 Hz, H-2"), 3.05 (dd, 1H, $J$ 16.7, 13.08, H-3" ax), 2.78 (dd, 1H, J 16.7, 2.8, H-3" eq), 2.20, 2.32, 2.38, 2.39 and 2.40 (s, 3H each, OAc-5,7,4',5",7"); ${ }^{13} \mathrm{C}$ NMR (50 MHz, $\mathrm{CDCl}_{3}$ ): $\delta 167.90(\mathrm{C}-2), 108.87(\mathrm{C}-3), 176.17$ (C-4), 155.87 (C-5), 113.85 (C-6), 160.97 (C-7), 109.11 (C-8), 153.96 (C-9), 111.50 (C-10), 133.56 (C-1'), 118.17 (C-2'), 148.80 (C-3'), 144.56 (C-4'), 124.66 (C-5'), 122.29 (C-6'), 78.97 (C-2"), 44.96 (C-3"), 188.99 (C-4"), 156.84 (C-5”), 110.55 (C6"), 163.11 (C-7"), 109.05 (C-8"), 150.11 (C-9"), 114.50 (C10"), 130.07 (C-1"'), 128.06 (C-2"”, 6"'), 118.54 (C-3"', 5"'),

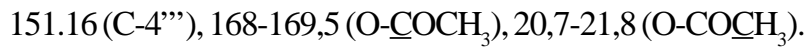

\section{Acknowledgements}

The authors are grateful to Conselho Nacional de Desenvolvimento Cientifico e Tecnológico (CNPq) and Coordenação de Aperfeiçoamento de Pessoal de Nível Superior (CAPES) for scholarships and financial support. We thank Dr. E. R. Silveira, Universidade Federal do CE, Fortaleza, Ceará, Brazil, for $[\alpha]_{\mathrm{D}}$ readings and NMR spectra (500 MHz for ${ }^{1} \mathrm{H}$ and $125 \mathrm{MHz}$ for ${ }^{13} \mathrm{C}$ ).

\section{References}

1. Velandia, J. R.; Ph.D. Thesis, Universidade Federal Rural do Rio de Janeiro, Brasil, 1997).

2. Felicio, J. D.; Gonçalvez, E.; Braggio, M. M.; Costantino, L.; Albasini, A.; Lins, A. P.; Planta Med 1995, 61, 217.

3. Moreira, I.C.; Sobrinho, D.C.; Carvalho, M.G. de; Braz-Filho, R.; Phytochemistry 1994, 35, 1567.
4. Oliveira, M. M. de; Sampaio, M. P.; Simon, F.; Gilbert, B.; Mors, W. B.; An. Acad. Brasil. Ciênc. 1972, 44, 42.

5. Monache, F.; D’Albuquerque, I.L.; Ferrari, F.Q.; Bettolo, G.B.M.; Tetrahedron Lett. 1967, 43, 4211; Ann. Chim. 1967, 57, 1364.

6. Rao, K. V.; Sreeramulu, K.; Rao, C. V.; Gunasekar, D.; Martin, M. T.; Bodo, B.; J. Nat. Prod. 1997, 60, 632.

7. Kamil, M.; Khan, N. A.; Alam, M.S.; Ilyas, M.; Phytochemistry 1987, 26, 1557

8. Okigawa, M.; Kawano, N.; Aqil, M.; Rahman, W.; J. Chem. Soc. Perkin I, 1976, 580.

9. Okigawa, M.; Kawano, N.; Aqil, M.; Rahman, W.; Tetrahedron Lett. 1973, 2003.

10. Thin, R. G.; Sondegam, M. T.; Martin, M. T.; Bodo, B.; Phytochemistry 1989, 28, 1557.

11. Thin, T. G.; Sondegam, M. T.; Martin, M. T.; Bodo, B.; Phytochemistry 1990, 29, 2289.

12. Ghogomu, T.; Sondegam, B. L.; Phytochemistry 1989, 52, 284.

13. Grynberg, N. F.; Mortorelli, R. A.; Carvalho, M. G. de; Braz-Filho, R.; Moreira, I. C.; Santos, A. C. S.; Echevarria, A.; Proceedings of the XVI International Cancer Congress 1994, p. 63.

14. Grynberg, N. F.; Brioso, P. S. T.; Velandia, J. R.; Echevarria, A.; Carvalho, M. G. de; Braz-Filho, R.; Proceedings of the XVII International Cancer Congress, 1998, p. 317.

15. Carvalho, M. G. de; Oliveira, M. C. C. de; Werle, A. A.; J. Braz. Chem. Soc. 2000, 11, 232.

16. Dora, G.; Edwards, J. M.; J. Nat. Prod. 1991, 54, 796.

17. Geiger, H. In The Flavonoids: Advances in Research since 1986; Harbone, J. B., ed.; Chapman \& Hall: London, 1994, pp. 95-115.

18. Markham, K.R.; Sheppard, C.; Geiger, H.; Phytochemistry 1987, 26, 3335.

19. Chari, V. M.; Ilyas, M.; Wagner, H.; Neszmélyi, A.; Chen, F.; Chen, L.; Lin, Y.; Lin, Y.; Phytochemistry 1977, 16, 1273.

20. Markham, K. R.; Tetrahedron 1976, 32, 2607.

21. Achambach, H.; Stocher, M.; Constenia, M.; A. Phytochemistry 1988, 27, 1835.

22. Linuma, M.; Mizuno, M.; Phytochemistry 1989, 28, 681.

23. Agrawal, P. K.; Bansal, M. C. In Carbon-13 NMR of Flavonoids; Elsevier: Amsterdam, 1989, pp 283-354.

24. Chaurasia, N.; Wichtl, M.; J. Nat. Prod. 1987, 50, 881.

25. Kojima, H.; Sato, N.; Hatano, A.; Ogura, H.; Phytochemistry 1990, 29, 2351.

26. Ahmad, V. U.; Aliya, R.; Perveen, S.; Shameel, M.; Phytochemistry 1993, 33, 1189.

27. Mahato, S. B.; Kundu, A. P.; Phytochemistry 1994, 37, 1517. 28. Olea, R. S. G.; Roque, N. F.; Quim. Nova 1990, 13, 278.

Received: November 1, 2000 Published on the web: December 12, 2001 